\title{
Formation and Development of Women's Non-Governmental Organisations in Central Asia
}

Ainagul Dyusembiyevna Bekebayeva, ${ }^{+*}$ Zhaslan Eseyevich Nurbayev, ${ }^{\dagger}$ Lazat Nurbayevna Nursultanova, ${ }^{\dagger}$ Aiman Maksotovna Azmukhanova ${ }^{\dagger}$ and Kunduzai Myrzashovna Yerimbetovaì

\section{Abstract}

This research examines women's organisations of the 20th and 21st centuries in the countries of Central Asia: Kazakhstan, Kyrgyzstan, Tajikistan, Uzbekistan, and Turkmenistan. It examines the formation process and the current state of women's non-governmental organisations in Central Asia and identifies new trends and areas in the development of women's socio-political movements in the region. The research is based on theoretical and analytical works reviewing the problem of formation and development of the women's movement in Central Asian countries. The systematic approach was used, alongside the historical and comparative methods. The findings reveal the following - limited mechanisms for equalising gender imbalances in society and increasing women's political representation in the quota system; insufficiency of financial and material resources of women's non-governmental organisations, based mainly on the assistance of international organisations and foundations; lack of active political initiatives of the women's electorate; the inadequacy of the national women's idea in the countries under study, which can consolidate both women's organisations and the female population.

Keywords: Women's Movement, Gender, Women's Non-governmental Organisations, Politics in Respect of Women

\footnotetext{
${ }^{\dagger}$ L. N. Gumilyov Eurasian National University, 000001, Republic of Kazakhstan, Astana, Satpayev Street, 2

${ }^{*}$ Corresponding Author Email: ainash11@mail.ru

İ Institute of History of the State, 010000, Republic of Kazakhstan, Astana, Manglik El Street, 8

C2019 Bekebayeva et al. This is an Open Access article distributed under the terms of the Creative Commons Attribution License (http://creativecommons.org/licenses/by/2.0), which permits unrestricted use, distribution, and reproduction in any medium, provided the original work is properly cited.
} 


\section{Introduction}

For the countries of Central Asia, one of the priorities of development is the development of an effective model of public organisations, their structure and effective management. These organisations have all the possibilities to ensure the adequate level of functioning of the statesocial system solving urgent socio-economic, globalisation and integration development problems. Women's public organisations are one of the forms of establishing optimal communicative interaction between individual actors of the public and government bodies in order to implement democratic changes in society. In modern conditions, it became necessary to establish the role of women in the system of social and political relations, in the structures of power, in the economy, science, and public associations. The activity of women's non-governmental organisations (NGO) and the dynamics of their development contribute to the improvement of legislation and legal mechanisms ensuring the improvement of the status of women, and to the development of a socially-oriented civil society.

The women's movement as a form of social activity and interaction of different generations serves as the basis for women to acquire relevant experience, socialisation and selfrealisation. The women's movement is an active subject of the creation and implementation of the new gender ideology, culture, sensitivity, consciousness and hermeneutics (Beasley, 1999; Bhattacharyya, 2009; 2013; Calman, 1992; Dahlerup, 1986; Einhorn, 1993; Kumar, 1993; Ryan, 1992). This is where the active and creative role of the women's movement in modern society is manifested (Beasley, 1999; Bhattacharyya, 2009; 2013; Calman, 1992; Dahlerup, 1986; Einhorn, 1993; Kumar, 1993; Ryan, 1992).

The revision of the modern concepts of the women's movement, as well as the search for an alternative ethno-sociocultural identity, is perceived ambiguously(Beasley, 1999; Bhattacharyya, 2009; 2013; Calman, 1992; Dahlerup, 1986; Einhorn, 1993; Kumar, 1993;
Ryan, 1992). Today, a woman realises herself not only by fulfilling the natural functions inherent in her, but also seeks new awareness of her authenticity, full disclosure of personal potential, and seeks alternative forms of sociopolitical and cultural identity. Perhaps, the \#metoo movement is a demonstration of this (Bhattacharyya, 2018). In this search, an important place is occupied by the possibility of an adequate representation of the feminine essence in the modern state-management and socio-economic culture, since traditionally in the system of patriarchal values, a woman was assigned the role of a passive object of social transformation (Beasley, 1999; Bhattacharyya, 2009; 2013; 2018; Calman, 1992; Dahlerup, 1986; Einhorn, 1993; Kumar, 1993; Ryan, 1992).

The problem of the women's movement, selfdetermination and development are urgent in international relations as well. This is due to the fact that this movement is designed to solve serious problems of the social development that affect the development of the state's democratic institutions, which impact international processes both in a single country and in the whole region. These problems are now extremely complex and require the involvement not only of local government bodies but also of international institutions.

The specificity of the socio-economic situation of the Central Asian states at the end of the last century led to the social activity of people who were acutely worried about unemployment, low wages, and poor quality of life for their families. It was during this period that a large number of public organisations were created, the purpose of which was the activity aimed at protecting legal, social, economic, creative, spiritual and other common interests (see, for instance, Watson and Clarke, 2014; Bhattacharyya, 2019). Among the most common varieties of social organisations are women's organisations expressing the specific needs and interests of women.

The main characteristics of women's social organisations are the existence of a common goal and the desire for cooperation and 
communication, as well as voluntariness, a clear organisational structure, hierarchy, unity and cohesion, creation of a system of rules and regulations that govern the relationships between members of the organisations and themethods of work.

The main functions of women's public organisations are as follows-organisational (creating new societies, attracting young people and new members; integrational (integration with regional and other organisations); ideological (defining its ideological role in the implementation of strategic and political tasks); educational (the formation of women's selfesteem, initiative); coordinational (establishing contacts between public organisations); creative-cultural (holding mass events); and charitable (protection of certain categories of women and provision of social assistance to them).

According to the target regulations, forms of activity and influence on the development of society, women's organisations are conventionally divided into four groups. The first group includes women's organisations that can be defined as historical or traditional. They were revived based on those women's organisations that operated in different historical periods in different territories of Central Asia in order to defend women's rights. Usually, these are mass associations of citizens, which are consciously formed to achieve long-term goals, have their own charters and an appropriate level of structuring. The creation of the second group of women's organisations was a response to social problems. This is the largest group of sociallyoriented women's organisations. The third group of women's organisations includes organisations of businesswomen, in which the economic activity of women is manifested. The fourth group consists of organisations that seek to solve local and specific problems that contribute to the development of women's selfconsciousness. In our opinion, gender centres that study the role of women in society should be identified as the fifth group of women's organisations.
In general, women's organisations can also be structured according to the criteria of the scale of activities, relationship to power, and the way they are created. According to the scale of their activities, international, country, regional and local women's social organisations are distinguished. International and country organisations enjoy greater autonomy and the ability to influence social processes. However, local and regional organisations are characterised by a high dependence on certain power structures. In relation to the authorities, public, public-political, and political organisations are distinguished. Public women's organisations have the goal of solving specific social issues, the public-political ones influence the solution of problems that have a political dimension, and the political ones are closely connected with political parties or independently try to solve power issues. In terms of the way of creation, one can distinguish formal and informal women's organisations. The formal ones operates on the basis of the principle of hierarchical construction and are characterised by a significant number. In informal organisations, there are no clearly defined leadership structure and hierarchy. They are mainly based on informal relations and personal friendships.

The typology of women's NGO in the countries of Central Asia will be discussed further.

In terms of the history of the issue under study, the degree of knowledge about the development of the women's movement in Central Asia was examined separately in each country. First, we studied theoretical papers and analytical articles on the issue in Kazakhstan, Kyrgyzstan and Tajikistan; where these scholarly papers are widely presented and freely available. Then we considered the countries where this problem has been studied poorly Uzbekistan and Turkmenistan.

Numerous research works appeared in Kazakhstan in the 1990s, concerning, among other things, the role of women's NGO in the construction of the state's social policy. The advantage of these studies is that they analyse the problems of modern social development, 
collect factual material about the state decisions (Ponomaryov, 1991; State and NGO: constructive dialogue 2004; Mersiyanova, 2012).

An important line of work of Kazakh scientists is the preparation of methodological literature, for example, the manual "Kazakh Women's Movement in the Context of Democratic Transformations in the Republic" (2001).

Separate problems concerning women's initiatives are presented by Ya.S. Akhmetova, who works with a number of NGO (The Conflict Center, The Feminist League, The Association of Business Women). In particular, the author states the following:

The Head of State's order to power structures to strengthen work with nongovernmental organisations is a new opportunity for non-governmental organisations. The state social order, which, despite all the reverses of fortune, is present in our country, and has already received a new stage of development, forced to reconsider many views on nongovernmental organisations and gives new forces to work in non-governmental organisations (Akhmetova 2003, p. 14).

Scholars argue that in Kazakhstan, the main condition for the emergence and development of the women's movement were their relationships with the state structures and international organisations (Korostyleva, 2005; Shishkarayeva, 2006; Syrtykbayeva, 1999). Since the mid-1990s, scattered studies on gender issues began to be conducted in Tajikistan. Of particular interest are the works by A. Kuvatova (1997), M.N. Hegay (1999) andM. Sharipova (2002).

The thesis entitled Women in a transforming society (by the example of the research on Central Asian states) is of great interest. This research examines the philosophical aspects of social problems triggering transformation of social policy and gender imbalance in the Central Asian societies; the formation of women's political activities; discrimination against women; the prospects for solving these and a number of other social problems (NurullaKhodzhaeva, 2004).

Similarly, the book titled Role of nongovernmental organisations in the formation of civil society in Tajikistan gives a detailed analysis of the work of the entire non-governmental sector. Here, the author describes the active operation of women's NGO in all sections, regardless of the type of operation: informationeducational, human rights, research, support of women's entrepreneurship initiatives (Karimov, 2015).

In a similar context, the following works on the history of the formation of women's organisations in Uzbekistan have been studied. These are- online report by D. Alimdjanova Women's Status in Uzbekistan (Alimdjanova, 2002), article by M. Kamp titled The New Woman in Uzbekistan: Islam, Modernity, and Unveiling under Communism (Kamp, 2007), PhD thesis by M.R. Kurbanova entitled Times of the Courage: Women's NGO Movement in Uzbekistan (Kurbanova, 2010), as well as public access reports of international organisations on the observance of human rights in Uzbekistan.

The most problematic field of the research was the review of the work of the researchers of women's movements in Turkmenistan. The research was carried out by the Union of Economists of Turkmenistan with technical assistance and close cooperation with the United Nations Development Program (UNDP) of Turkmenistan (Gender and Business in Turkmenistan, 2008). The problem of the rights of women and women's NGO is reflected in the article written by the founder and editor of the website, Saglyk.info A. Yailymova. In her article One Step Forward, Two Steps Back: 25 Years of Women's Rights in Turkmenistan, she describes the changes that have taken place in Turkmen society since the Soviet Union collapse, which involves issues such as women's access to education, women's economic opportunities, state social support, women's social inclusion mechanisms and other issues. According to the author:

... one of the first state initiatives should be the registration of independent 
organisations and groups for the protection of women's rights. Independent organisations should be considered as a part of the solution of those complex issues that women face today (Yailymova, 2017, p. 58).

Formation and Development of Legislative Framework Aimed to Protect Women's Rights in the Central Asian countries

Almost all the Central Asian countries have joined the main international documents on creating conditions for the gender equality development, such as the Convention on the Elimination of All Forms of Discrimination against Women (1979) and the Convention on the Rights of the Child (1989). These fundamental documents reflect the transition from a simple proclamation to determine the issues to take the measures necessary to implement these rights. The Platform for Action adopted at the Fourth World Conference on Women in 1995 defined a set of measures aimed to implement the provisions of the Convention on the Elimination of All Forms of Discrimination against Women. It has been recognised that the discrimination against women and girls, when distributing economic and social resources is a direct violation of economic, social, political and cultural human rights (Convention on the Elimination of All Forms of Discrimination against Women, 1994; On the implementation of the decisions of the Beijing Platform for Action on the Status of Women in respect of women's rights, 2001; The UN Convention on the Child's Rights, 2002). Due to these international documents in 2018, there have been significant changes in the sphere of gender relations in the countries of Central Asia. However, it is still too early to say that discrimination has been eliminated. One should consider the legal framework of the countries under study separately, regarding the role, place and the rights of women in society.

In Kazakhstan, a sufficient legal framework has been created on family, women's and children's issues, providing understanding of the family's importance in the society, its role in educating new generations, ensuring public stability and progress, recognising the need to take into account the interests of the family and children, and adopting special measures for their social support.

The following regulatory documents protect women's rights in Kazakhstan: Constitution of the Republic of Kazakhstan, the Laws of the Republic of Kazakhstan- On the Prevention of Domestic Violence, On Marriage (Matrimony) and Family.

In order to reach the goal of gender balance of opportunities, the National Commission for Family and Women Affairs under the President of the Republic of Kazakhstan was established in 1998. The Government Decision dated July 19, 1999, No. 999 approved the National Action Plan for the Advancement of Women in the Republic of Kazakhstan. This document outlined the main goals for achieving gender equality. The Presidential Decree dated November 29, 2005, approved the Gender Equality Strategy in the Republic of Kazakhstan for 2006-2016, which set the goal to achieve a $30 \%$ women representation among the heads of state bodies.

In 2017, a new document on gender policy entitled-The concept of family and gender policy in the Republic of Kazakhstan until 2030 was adopted (On the approval of the Concept of Family and Gender Policy in the Republic of Kazakhstan until 2030 n. d.). This strategy is important for achieving gender equality in Kazakhstan, as it sets certain benchmarks and standards. The public and activists were able to influence the consideration of some issues such as gender-sensitive budgeting, the implementation of the UN Security Council resolution No. 1325 on Women, Peace and Security, and the expansion of women's economic opportunities.

Today, Kazakhstan is a member of more than 60 different human rights treaties and conventions, including those aimed at ensuring equality between sexes, as well as protecting women and children. Despite the fact that since the withdrawal from the USSR, Kazakhstan has made some progress in protecting the rights and legitimate interests of men and women. However, the state has a long way to go to 
overcome the existing gender stereotypes and to liquidate the patriarchal remnants that are still quite strong in the society, as evidenced by the study conducted in 2016 by the Public Foundation - Institute of Equal Rights and Equal Opportunities of Kazakhstan with the support of the Friedrich Ebert Foundation Representative Office in Kazakhstan (Gender research: How does Kazakhstan implement a policy on women and men n. d.).

Kyrgyzstan. The observance of women's rights remains an important part of the entire democratic process in Kyrgyzstan, which proclaims itself to be a country of human rights. Here, women's rights are viewed through the prism of human rights and protected by the country's Constitution and national legislation (Review of trends in achieving gender equality in the Kyrgyz Republic n. d.).

Equal rights and opportunities for women and men are entrenched in the international and national obligations of the Kyrgyz Republic. Over the years of independence, Kyrgyzstan has joined a number of international conventions, including the Convention on the Elimination of All Forms of Discrimination against Women, and the gender equality is an integral part of human rights and freedoms provided for by the Constitution of the Republic of Kyrgyzstan.

Since 1996, the National Statistical Committee of the Republic of Kyrgyzstan, with the support of UNDP, has been publishing the annual statistical digest-Women of the Kyrgyz Republic, and since 1999 - Men and Women of the Kyrgyz Republic.

In addition to the Constitution, the legal framework for gender policy in Kyrgyzstan is based on regulatory acts as the Law of the Kyrgyz Republic - On State Guarantees for Equal Rights and Equal Opportunities for Men and Women dated August 4, 2008 No. -184, and the Law of the Kyrgyz RepublicOn Social and Legal Protection from Domestic Violence dated March 25,2003 , No. 62 , as well as the Family Code of the Kyrgyz Republic, adopted in 2003.

The Parliament of Kyrgyzstan has ratified a number of UN conventions directly related to women's issues, in particular: on the political rights of women; on the consent of marriage; marriage age and marriage registration; on the citizenship of a married woman; on the elimination of all forms of discrimination against women.

Adoption of specialised national programs on the gender equality, at the first stage, involved the national program - Ayalzat- a national action plan based on the Beijing Platform for Action for the Advancement and Promotion of Women (1996-2000). The main goal of the national program Ayalzat, was to achieve a qualitative turnaround in the advancement of women by 2000 . The national program created conditions for significant progress in achieving real equality between men and women, increasing women's opportunities and creating favourable conditions for the development of equality.

The second step in the implementation of the country's gender agenda was the National Action Plan, approved by the Decree of the President of the Kyrgyz Republic No. 52 dated March 2, 2002, which aimed at forming a gender equality policy.

The Decree of the Kyrgyz President No. 369 dated August 20, 2007 adopted the second National Action Plan for achieving gender equality in the Kyrgyz Republic for 2007-2010, which was the basic document defining the state gender policy, its goals, objectives and principles, directions and priorities within the framework of the Country Development Strategy for 2007-2010.

The period of 2012-2014 can be considered the third stage in the implementation of the country's gender agenda. For the first time, a long-term National Strategy for Achieving Gender Equality until 2020 (approved by Government Decision of KR No. 443 of June 27, 2012) was developed and adopted, which was determined by the need to strengthen gender policy mechanisms in the context of deepening the social inequality caused by political and economic crises of recent years. For the first time in the history of sovereign Kyrgyzstan such country documents as the National Strategy for 
Sustainable Development until 2017 and the Program and Plan of the Government of the Kyrgyz Republic for the transition to sustainable development for 2013-2017 singled out the issues of women, family and gender development as one of the priorities of sustainable development. The proposed tasks and measures are fully consistent with the goals and objectives defined in the National Strategy for Achieving Gender Equality until 2020 (2012).

In general, the republic's legal framework meets international requirements and is an important link in the observance of human rights.

Tajikistan developed the National Plan for the Enhancement of the Women's Status and Role for 1998-2005. On December 12, 1999, the Presidential Decree on Increasing Women's Role in Society was issued. It was concretised by the adoption of the State Program for Ensuring Equal Rights and Opportunities for Women and Men for 2001-2010.

The main agency responsible for Tajik gender policy is the Committee for Women and Family Affairs. This institution not only actively develops and implements strategies and sectoral programs but also promotes the economic empowerment of women. The Committee also coordinates the work of governmental organisations and NGO on gender equality.

In order to create the necessary conditions for the women's abilities in all spheres of society, in 2011, Tajikistan adopted the National Strategy for Activating the Women's Role in the Republic of Tajikistan for 2011-2020, as well as more than 80 presidential grants of 2 million somoni from the country's budget for the development of women's entrepreneurial activity (National Plan for the Enhancement of the Women's Status and Role for 1998-2005 n. d.; National strategy of activating the women's role in the Republic of Tajikistan for 2011-2020 n. d.).

All the combined laws and programs potentially provide the legislative and programmatic framework necessary to fulfil international obligations in human rights and women's rights. However, the existing reality does not reflect legal guarantees for women's exercise of their rights and equality.

The women's rights in Uzbekistan are reflected in the Constitution of the country, as well as in the Presidential Decree entitled On Measures to Enhance the Women's Role in the State and Public Construction of the Republic of Uzbekistan (March 2, 1995) and in the presidential decree On additional measures to support the Women's Committee of Uzbekistan (May 25, 2004). The adoption of the National Platform of Action for the Advancement of Women in Uzbekistan and the Enhancement of Their Role in Society (1999) and a number of international documents are of great socio-political importance since they cover all spheres of women's lives and are aimed at increasing their social status and improving living standards.

Adopting a number of legal documents and programs to accelerate the development of civil society institutions significantly and at the same time, the entire process of democratic transformation in the country is of great importance for the further development of the democracy and gender equality in Uzbekistan.

However, despite the gender equality norms, Uzbekistan does not yet have "a special mechanism for implementing, monitoring and reporting on provisions against discrimination". For example, there is no legal definition of gender discrimination within the framework of national legislation. In particular, a bill was prepared to guarantee equal rights and opportunities for women and men, which was sent for consideration to the Legislative Chamber of Oliy Majlis (Parliament) in 2006. It assumed further support for the protection of equality "in the state, social, economic and cultural spheres". NGOs noted that, if there is no special law on equality, international organisations and civil society groups make efforts to amend the existing legislation for it to include more explicit provisions against discrimination (Asian Development Bank 2014).

Turkmenistan is the fifth Central Asian country. Despite a common historical past, this country differs significantly from its neighbours by internal, unspoken laws and traditions. 
Legislatively, to all citizens of Turkmenistan, without any distinction based on sex, the Constitution and laws of the country guarantee the legal, including judicial, protection of rights from any manifestations of their discrimination.

Turkmenistan has adopted the Declaration on International Obligations in the Human Rights and Fundamental Freedoms after the declaration of neutrality status, which was approved by the UN General Assembly on December 12, $1995 . \quad$ Observing this commitment, Turkmenistan has equated national legislation with the international standard on the women's rights and freedoms and ratified key documents such as the Declaration on Human Rights, the International Convention on Economic, Social and Cultural Rights, the Declaration on the Elimination of Discrimination Against Women, the Convention on Child's Rights, etc.

The first National Action Plan of Turkmenistan on gender equality, approved by the Decree of the Turkmenistan President, was adopted in January 2015 and was aimed at combating gendered violence and eliminating discrimination against women (The National Action Plan on Gender Equality n. d.). Its tasks include promoting women's equal access to quality education, healthcare and the labour market and strengthening the country's national capacity to report, monitor and implement the Convention on the Elimination of All Forms of Discrimination against Women and other human rights obligations of Turkmenistan related to gender equality.

Despite the accession to all available human rights documents, Turkmenistan has quite visible discrimination against women and girls, which manifests in such tacit prohibitions as banning driving, wearing swimsuits and shorts, dying hair and using nail extensions. Moreover, it is also not recommended to wear gold jewellery (The National Action Plan on Gender Equality presente n. d.). Since 2013, participants of various events or employees of state institutions, as well as students of local universities, have been forced to wear dresses of the same scarlet colour and a national scarf. All these prohibitions demonstrate the strong patriarchal traditions of Turkmen society, which began to intensify during the reign of current president G. Berdimuhamedov. The following section presents the types of Women's NGOs In Cental Asia

\section{Typology of women's NGO in Central Asian countries}

Today, there are three types of women's NGOs in the region under study. The first is rooted in the history of trade unions, Soviet public organisations with a developed infrastructure, good material base and liberated cadres. Women's NGO of this type are the heirs of former women's committees with an authority, relations with provinces, exciting ideological work experience, broad contact network and access to power echelons.

The second type of NGO are associations that are more professional: associations of women entrepreneurs, artists, credit unions, farmer associations, etc. These are organisations that help women to survive and find their own business during the economic crisis.

In terms of the business line, women's NGO can also be classified into several broad groups: (a) NGO engaged in the development, social projects in the city and in the countryside; (b) various funds engaged in charitable and cultural activities; (c) NGO engaged in scientific, practical and research activities that promote the professional development of their members.

Women's organisations have made a great contribution to the development of the women's movement in Kyrgyzstan. Some of these organisations are: the International Charitable Fund -Meerim; Diamond Association; Women's Aid Center, Association of Independent Academic Lawyers, Manas Covenants XXI Century, Rural Women's Union Alga, Coalition of NGO and many others. They carry out not only social projects but also programs aimed to increase the legal literacy of women, train political skills and leadership, etc. Currently, in many women's NGO, the gender perspective of problems begins to dominate over women's interests, which 
characterises their significant qualitative growth.

In November 2001, in Kazakhstan, Almaty hosted the founding conference- Coalition of Independent Women's Organisations, whose tasks are to protect and lobby the interests of women's NGOs (primarily in the regions). The coalition works to expand women's legal rights, their real representation in all spheres of professional and public life, and to promote women's credit programs. The Coalition has undertaken the tasks of providing educational, legal and financial support of women's rights for the development, creativity, and freedom in manifesting their capabilities (Women's NGO are united in a coalition, 2001).

The difficulties of developing the women's movement are connected both with objective reasons, characteristic for the entire social sector and with a number of specific problems. The most significant of them consists in the fact that some states in this region, such as Uzbekistan and Turkmenistan, do not only show any interest in the civil society development but also in every way hinder its development. Most countries of the Commonwealth of Independent States (CIS) have no progressive policy that provides tax incentives to potential sponsors, which would allow finding domestic resources to develop the third sector. The practice of issuing state grants on a competitive basis for the civil initiatives in the regions has not worked out.

Lobbying by NGO leads to the improved government decrees and to the focused attention on the women's movement problems as a whole. It is through the activation of NGO that the current civil society is being formed in the post-Soviet states. Combining these efforts, creating regional teams can help to coordinate the fieldwork clearly and vividly.

\section{Women's NGOs in Kazakhstan}

If by mid-1994 only six women's NGOs was registered in Kazakhstan (Akmola Committee of Soldiers' Mothers, Union of Kazakh Women, League of Muslim Women, Union of Large Families of the Republic of Kazakhstan, Feminist League, Kazakhstan Association of Disabled
Women with Dependent Children), then in 1997, there were already 30 , and by early 2003 -about 200. Today, women's organisations in the form of association are represented by three groups: non-governmental (such as the Crisis Center Girlfriends, Association of Single Mothers, Women's Election Bloc, etc.), state (National Commission for Family and Women Affairs under the President of the Republic of Kazakhstan), international (UNIFEM - the United Nations Women's Fund).

The NGOs in Kazakhstan today have different goals and address the widest audience. Among them are women's organisations that are related to education (The Union of Women of Al-Farabi Kazakh State National University), mothers and children (Association of Parents of Disabled Children, Kazakhstan Union of Large Families, Association of Single Mothers-Moldir, Almaty Committee of Soldiers' Mothers and others), health problems (Republican Society of Disabled Women with Dependent Children Bibi-Ana, Republican Center for Mother and Child Health), crisis centers (Crisis Center Girlfriends, Care, Forget-me-not),, professional issues (Women's League of Creative Initiative, Association of Women Lawyers); environmental issues (International Environmental Association of the East Women, Greenwomen), Muslim organisations (League of Muslim Women) and others. In addition, Kazakhstan has two Centres for Gender Studies (CGS): in Alma-Ata (headed by S. Shakirova) and Karaganda (headed by $\mathrm{N}$. Usacheva). There are two Feminist Leagues: in Alma-Ata (the president is E. Kozyreva) and in Kokshetau (the president is G. Morozova). The number of employees of these organisations is from one person in the asset to several dozens. It is difficult to say how many women have actively participated in the women's movement to date because their number is constantly changing (Women's movement in Kazakhstan: Ten years of history $n$. d.).

Crisis centres in Kazakhstan were formed in the late 1990 s and by 2018 their number reached 30. There is even a Union of Crisis Centers of Kazakhstan - a voluntary association of legal entities registered in the Almaty City 
Department of Justice on March 26, 2001. The Union of Crisis Centers of Kazakhstan is an NGO whose activities are aimed at developing the movement in the prevention and eradication of all forms of gender violence, the formation of a culture based on the values of non-violent relations in society. The Union unites 13 organisations from 11 regions of Kazakhstan.

In February 1999, the system of the Ministry of Internal Affairs established a special unit aimed to organise departments for protection of women against violence (Order of the Ministry of Internal Affairs dated 26.10.1999 N 535 -On issuing instructions on the organisation of the work of units of the internal affairs bodies of the Republic of Kazakhstan to combat violence against women, 1999). Almost immediately, these departments started to actively cooperate with women's NGO. In 2002, in the crisis centre Care, the inspectors on the protection of women against violence began to work. The crisis centre Girlfriends has conducted special bilateral training with employees of 54 precincts of Almaty. However, only the police and the crisis centres were involved in the cooperation.

One of the types of violence, which is an acute issue in Kazakhstan, is the illegal involvement of women in the field of sexual services (sex trafficking). It is also saddening to note that sex trafficking is rampant too in South Asian countries like India and Nepal where the government resources allocated to tackling this form of crime against women are meagre and the crime is on the rise (Bhattacharyya, 2017; Dhungel et al., 2019).

Unfortunately, in Kazakhstan, this phenomenon has become outrageously familiar and is commonly ignored alongside the issue of domestic violence) (Kazakhstan: Domestic sex trafficking is greater than in the UAE, Turkey and Russia 2015). The reason for such an attitude to this problem may be the patriarchal type of thinking of the majority of the country's population. For example, if women who could not find high-paying jobs in the country go to work in other countries, they are disapproved of by their compatriots. As for domestic violence, according to the traditions of Kazakh society, a woman should silently endure all kinds of discrimination by her spouse and his relatives. Even complaints to law enforcement agencies receive no attention due to the imperfection of the legislation on domestic violence. This observation resonates with the findings of developing countries like India and Bangladesh (Bhattacharyya, 2015; Bhattacharyya et al., 2018; Das et al., 2015; 2016; Vauquline, 2015).

The issue of women's power and representation in power structures and at all levels of the government is even more a difficult task. During the pre-election presidential and parliamentary campaigns of 1998, women's organisations, united in the Coalition-Women's Electoral Initiatives (later expanded into the Women's Electoral Bloc), compiled an open letter to presidential candidates. One of the demands of this letter was a $30 \%$ quota for women in all government structures.

The Council on the Family, Women and Demographic Policy Problems that existed before the end of 1998 did not justify itself, and there was a need for another, more powerful structure. As a result of the purposeful actions of women's NGOs, on December 22, 1998, president N.A. Nazarbayev issued a Decree, which resulted in the formation of the National Commission for Family and Women Affairs as an advisory body under the President of the Republic of Kazakhstan. Similar commissions were established under the aims of the regions and the cities of Astana and Almaty.

The first national report was prepared in Kazakhstan in 2000. It was a joint work of the government organisations and the NGOs. Women's organisations believe that the report turned out to be fairly objective. However, the many cases, on which NGO and the state have disagreements, testify to the actual situation of women in Kazakhstan. The Feminist League published a book entitled "Women of Kazakhstan", which clearly shows the discrepancies in figures and facts, such as the maternal mortality ratio, the number of women in science, the payment of childbirth allowances, etc. From these discrepancies, it is concluded that the state sees women's situation differently 
than women themselves - representatives of NGO. The first alternative report on women's situation was prepared by the Feminist League in 1997.

According to statistical data published in the annual Statistical Digest of Kazakhstan (Statistical Yearbook: Regions of Kazakhstan in 2016 n. d.) from 2015 to 2017, there was an increase in the number of NGOs with a larger number of organisations accounting for the city (Table 1). This can be explained by the fact that in the rural areas of Kazakhstan, the population is less mobile and less socially-active due to poor access to internet resources, insufficient information policy, and higher engagement in domestic problems.

\begin{tabular}{|c|c|c|c|c|c|c|}
\hline \multirow[t]{2}{*}{ Years } & \multicolumn{3}{|c|}{ Number of Registered NGOs } & \multicolumn{3}{|c|}{ Number of Existing NGOs } \\
\hline & Total & City & Village & Total & City & Village \\
\hline $\begin{array}{l}\text { as of January 1, } \\
2015\end{array}$ & 22,771 & 19,483 & 3,288 & 10,329 & 8,451 & 1,878 \\
\hline $\begin{array}{l}\text { as of January 1, } \\
2016\end{array}$ & 23,125 & 19,713 & 3,412 & 11,089 & 9,144 & 1,945 \\
\hline $\begin{array}{l}\text { as of January 1, } \\
2017\end{array}$ & 24,221 & 20,607 & 3,614 & 12,002 & 10,066 & 1,936 \\
\hline
\end{tabular}

Source: Women's NGO are united in a coalition (2001)

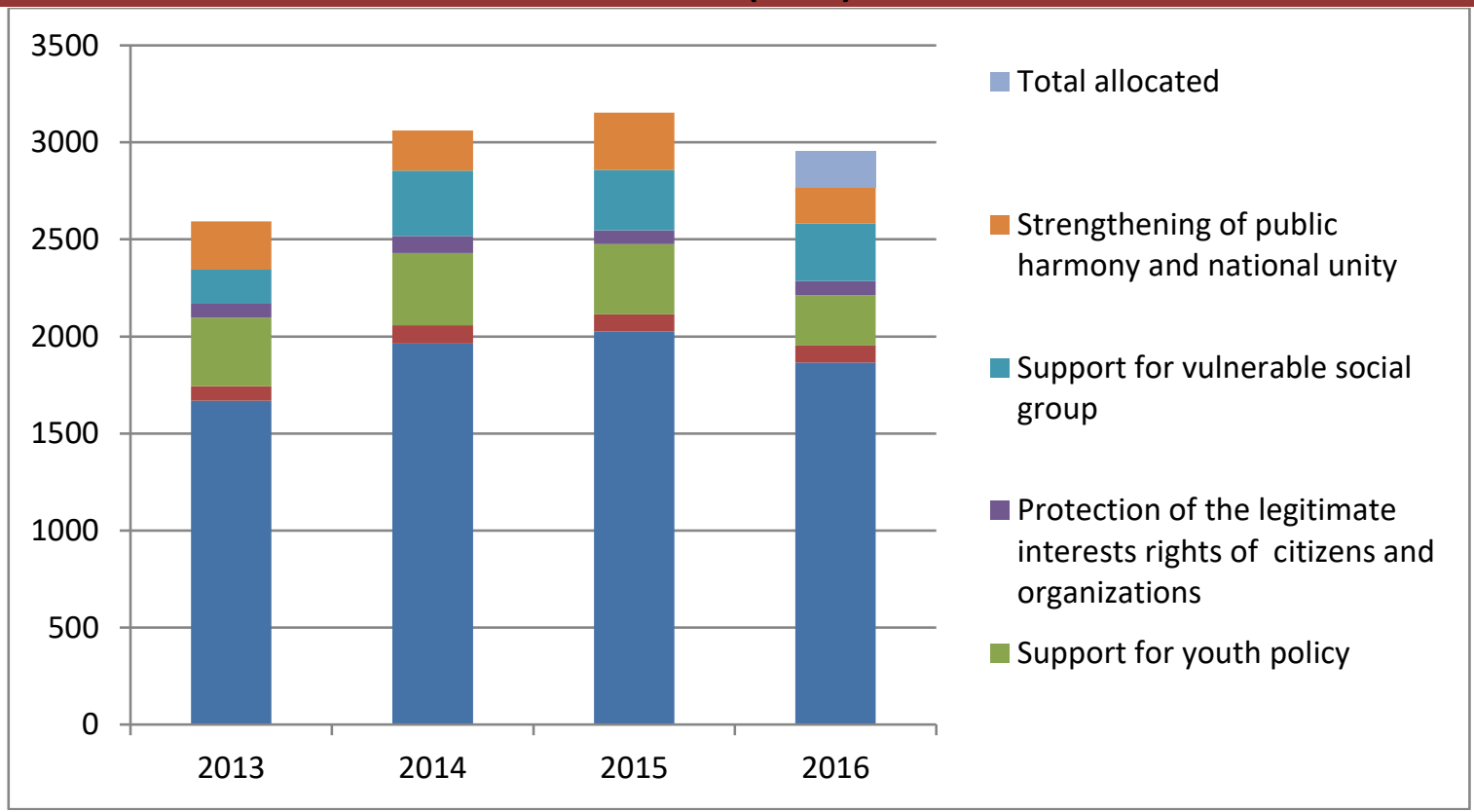

Figure 1: Distribution of the state social order in the Republic of Kazakhstan by the business lines

Source: Statistical Yearbook: Regions of Kazakhstan in 2016 n. d.

Figure 1 shows that in recent years in the Republic of Kazakhstan, out of the total number of grants allocated by the state, areas as support for socially-vulnerable segments of the population, youth policy and the strengthening of social cohesion and national unity are the top priorities. In comparison with the listed directions, funding for the solution of gender problems and protection of the legitimate interests of the citizens and organisations is smaller.

\section{Women's NGOs of Kyrgyzstan}

One of the first women's NGOs is the Women's Committee of the Kyrgyz Republic (chairperson Sh.l. Kudabayeva), the successor of the Republican Women's Council. The organisation was registered in 1991. The main tasks of the committee are as follows: to promote 
democratic reforms in Kyrgyzstan, to participate in the implementation of the state programs of Ayalzat and Araket; to solve problems of women during the transition period; to protect their interests and involve them in enterprise activities. The impetus for the modern women's movement was set by the participation of 25 Kyrgyz women (head of the delegation R.I. Otunbayeva) in the IV World Conference on Women in Beijing (1995) and the ratification of the UN Convention on the Elimination of All Forms of Discrimination against Women. The researcher, K.A. Bekturganova notes that if in 1994, only a few NGOs functioned in Kyrgyzstan (the Women's Committee of the Kyrgyz Republic, the Women's Congress of Kyrgyzstan, the ICF Meerim, Diamond, the Forum of Women's NGO, the League of Women for the Development of Folk Traditions, Customs and Cultures), then as of January 1, 1997, there were already 47 women's organisations. According to the Ministry of Justice, in 2002, in Kyrgyzstan, out of more than two thousand NGOs, 160 NGOs worked in the field of women's rights (Bekturganova, 2009, p. 125).

The Democratic Party of Kyrgyz Women (chairperson T.A. Shailiyeva) was founded in 1994. It is a women's political party established to promote the building of a truly democratic society and rule of law, achieving women's genuine equality in all spheres of life, protecting women's interests, solving problems of the family, motherhood and childhood. The party's goal is to achieve the implementation of women's rights in public authorities, the women's right to elect and be elected.

International Association Diamond (chairperson B.G. Tugelbayeva) was founded by female teachers and research workers of higher education institutions in 1994. Its main business lines are women's/gender studies, women's rights, their health, women's place in politics, society and family, achieving gender equality in society and state. The Association has published a number of books. They are - Women of Kyrgyzstan: traditions and new reality, Insecurity of gender protection, Women's rights and their protection in Kyrgyzstan, etc.
The Center for Gender Studies (CGS) (chairperson Zh. Abdyldabekkyzy) was established in 1997. The organisation's mission is to promote equal rights and opportunities in social life regardless of gender, nationality, age, occupation, religion, etc. During the election campaign of 1999-2000, this centre promoted and supportd women. In addition, it has worked towards the development of the National Action Plan for Achieving Gender Equality in Kyrgyzstan for 2002-2006, the draft law On Gender Policy in the Kyrgyz Republic, etc.

The Public Fund for Support of Women's Business and Community Initiatives - DatkaAyim-Akylman (president B.A. Utirova) is an NGO created for the support and protection of women's rights and interests in the field of entrepreneurial, social and educational activities.

The Kyrgyzstan Federation of Women's Organisations (chairperson J.Ch. Tashibekova) was established in May 1998. It consists of 112 women's NGOs from all regions of the republic. The main activities of the Federation are as follows: to stimulate, consolidate and strengthen women's NGOs in Kyrgyzstan and integrate them into the international women's movement, to study gender, to support women's leadership, etc.

Women's Aid Center (WAC) (president R.T. Aitmatova) was established on the initiative of female teachers of higher education institutions and activists of women's organisations in 1996. WAC helps women to adapt to the new economic conditions and encourages their participation in building a healthy economy and democratic society. WAC published more than 10 works, including-Democracy, Gender and Women's Rights (2000, 2002); Rational nutrition (2001); Gender School in Kyrgyzstan (2003); Agribusiness rate (1999) (http://wsc.host.net.kg).

The Kyrgyzstan Congress of Women (president Z.A. Akbagysheva) was founded in 1993. With the help of the Congress, more than 10 thousand women were trained in the basics of entrepreneurship, English, German, Turkish, 
Kyrgyz languages. A total of 750,000 women benefited from the charity.

The Kyrgyzstan Forum of Women's NGO (chairperson N. Dzhanaeva) was established in 1994. More than 80 women's NGOs working in different areas are the members of this Forum. The main directions of work are as follows: to join efforts in the activities of NGO through the involvement of women's NGOs in Kyrgyzstan and Central Asia aims to interact and build a partnership with state structures, foreign and international women's organisations. The further development of the Kyrgyzstan Forum of Women's NGOs led to the creation of the Central Asian Forum of Women's NGOs, which unfortunately does not function efficiently now.

Bishkek Women's Center Public Association (chairperson G.K. Aitbayeva) was established in 1996. The goal of the organisation is to promote the realisation of women's potential to improve their social status and life quality.

In 2004, 13 crisis centres were established in the republic. The main directions of their work are to protect women from domestic violence, combat women's sexual exploitation and trafficking. The first Kyrgyzstan counselling and prevention centre Chance (chairperson A. Eliferenko) and the crisis psychological centre Sezim for women and the family (chairperson B. Ryskulova) - are among the first organisations in Central Asia (1998), which addressed the problem of violence against women and children.

The Kyrgyzstan Association of Crisis Centers (ACC) (president M. Tilebaliyeva) was established in 2001. It unites 13 crisis centres. Its goal is to promote the elimination of discrimination against women in all spheres of the public and private life of members of society (Association of Kyrgyzstan Crisis Centers n. d.). Its tasks are as follows: to consolidate women's movement, develop a network of crisis centres at the local, regional and international level. The Association provides methodological support to crisis centres through training, develops the network, work between the crisis centres in Kyrgyzstan and abroad for the purpose of exchanging information and experience, promotes a non-violent way of life through the media, conducts conferences and seminars, lobbies the laws that protect women's rights and interests, evaluates projects and programs.

\section{Women's NGOs of Tajikistan}

The first NGO of the new type appeared in the Republic of Tajikistan in the early 1990s. Women's NGOs in Tajikistan are the main driving force in the struggle for equality between men and women, and very often, their initiatives outstrip the government's actions. Their activities attract the attention of society and state structures to gender issues, provide real and practical assistance to women in various fields.

The republic had only three women's NGOs in 1995. However, by the end of 2000, their number reached 70, and by August 2001, there were 135 women's NGOs and two other NGOs, whose programs are aimed at improving women's status.

By 2001, the women's movement of the republic consisted of 34 NGOs of national importance, five of them had the status of an international organisation. Among them are the international public association Jomea va Peshraft, the Tajik branch of the international organizationWomen in the Central Asian media, the Tajik branch of the International Fund for Humanitarian Cooperation- She, the International Fund-Huboni Porsigu, the Tajik branch of the international association Women of the East(Mirzoyeva 2004, p. 50)

At the regional and oblast ${ }^{1}$ level, there were 36 women's NGOs; at the district level - 46 and in the cities of the Republic -24

The development of the women's nongovernmental movement in Tajikistan was greatly facilitated by the joint project of the government and UNDP- Women in Development, which began its work in 1995. From this time on, their activities started introducing and developing gender policy in the country.

It remains well gegisted that including representatives of NGOs in the lawmaking process and the development of strategic 
documents makes it possible to take into account a wide range of opinions and approaches, and to determine the most optimal ways of solving problems. For example, representatives of the NGOs- Women of Science of Tajikistan and Gender and Development participated in the development of the State Program -Main Directions of State Policy on Ensuring Equal Rights and Opportunities for Men and Women in the Republic of Tajikistan for 2001-2010 (Public Association - Gender and Development and EU, 2004).

Over the past few years, Tajik NGOs supported by international agencies have successfully implemented a number of civic educational projects. For example, the organisationsTradition and Modernity, Umed, Nilufar, Women-Voters, Orzu, Oshtii Milli, Khilola, Fidokor, Association of Women with University Education, the club Lady-Leader and many others conduct seminars, training and other activities linked to women's rights, gender relations and strive to prepare local women to participate in the country's political life.

In October 1998, Dushanbe held the Tajikistan First Forum of Women's NGOs, prepared by the Bureau Women in Development, which was assisted by the Government of Tajikistan and the UNDP. This forum noted that women's NGOs carry out their activities in the most diverse spheres of society: education, health, science, culture, agriculture, ecology, social support and assistance to veterans and disabled people.

One of the most significant NGOs in the republic until 1999 was the Women's Union of Tajikistan. As the unifying body of all women's NGOs, the Union carried out all work in close cooperation with them. In March 1998, the Women's Union launched an educational program for rural girls. Currently, the Center trains 136 girls from 37 regions of the country. $60 \%$ of them received diplomas from the university in Dushanbe and certificates of graduation from the Training Center. However, in 1988, was established the Simowas Association of Women of Tajikistan, which is considered one of the first women's NGOs. Professor M. Shakhobova was the founder and head of the organization until 2003. The main objectives of this organization are the social protection of women, the achievement of genuine independence and equality.

Similarly, the Association of Women with University Education, headed by a well-known public figure G.B. Bobosadykova is actively engaged in legal and educational work.

At the initiative of the women of science and the corresponding member of the Academy of Sciences of the RT, Professor M. Yakubova, the Association, Women of Science of Tajikistan was established, which actively deals with gender issues and reproductive rights. The Association has a Center for the Psychological Rehabilitation of Women, which is a special wing for those women who suffer from physical and emotional violence.

Besides, associations located in the Sughd region- Women and Society, Women for Progress, Women of the East, etc. are actively engaged in socio-economic problems of the modern woman, her participation in the society's democratic transformation, and protection of her rights.

In the Khatlon region, NGOs -Lady Leader, Women's Society, Women's Union, Women's Center of Shaartuz District and others increase the women's labour and socio-political activity.

In addition, the women's NGOs Madad and Madina function in the Gorno-Badakhshan Autonomous Region. They assist in the employment of women and girls.

The problems of the economic development of local communities, the involvement of women in self-employment are dealt with by NGOs of the districts of the republican subordination Bonuvon of the Kofarnihon district, Nilufar of the Varzob district, Mekhrubon of the Tursunzade city and several others.

\section{Women's NGOs of Uzbekistan}

Currently, many women's NGO are active in Uzbekistan. Women's problems are solved by Uzbekistan Association of Business Women, Woman and Health, Women's Society, 
Mehrymiz Sizga, Republican Scientific and Practical Center- Oila and others.

During the first 15 years of independence, 177 women's NGOs were registered in the republic (Responses to the list of issues and questions for consideration of the Combined second and third periodic report of Uzbekistan 2006), including the Women's Committee of Uzbekistan, the International Women's Fund "Sharq ayoli", the National Association of Entrepreneurs of Disabled Women of Uzbekistan, the National Association for Breast Cancer - In the name of life, the Republican Public AssociationWomen's Assembly, whose activities are aimed at forming a healthy family, protecting women's rights, supporting women entrepreneurs, and increasing their professional, physical, spiritual and intellectual development.

The Women's Committee extensively engages NGOs in its activities. Due to the productive cooperation between the Women's Committee, NGOs and financial institutions, some progress has been made in improving the system of monitoring the legislative base and collecting statistical data. For example, in 1996, the Gender and Development Bureau, funded by the UNDP, was established within the Women's Committee. One of the tasks of this Bureau is to assist the Department of Statistics in collecting, analysing and publishing disaggregated statistics taking into account gender distinctions.

The joint collaboration between the Women's Committee, the Gender and Development Bureau, and numerous NGOs resulted in the publication of the Report on the Status of Women in Uzbekistan (Women's Committee of Uzbekistan, Gender and Development Bureau and UNDP, 1999). The report, funded by UNDP reflects the conclusions and point of view of independent writers, including the representatives of women's organisations, mass media analysts and journalists, lawyers and economists, and testifies to the awareness level of gender inequality in Uzbekistan, as well as the desire to solve this problem.

\section{Women's NGOs of Turkmenistan}

The most influential women's organisation is the Turkmenistan Union of Women, which has about a million members in its ranks. The supreme body of the women's organisation is the Congress of the Union, to which authorised representatives from its territorial divisions are delegated.

The International Meeting of the Female Heads of Parliament was an important event in the history of the international women's movement. The forum demonstrated the relevance of the interaction of women parliamentarians and the great positive potential of such cooperation for strengthening peace and mutual understanding at the regional and global levels. Representatives of more than 50 countries participated in the meeting, with 32 delegations led by female speakers, including the Turkmen delegation.

The participants discussed the results of the previous, 9th meeting, which took place in 2014 in Geneva, as well as topical issues of multilateral interparliamentary cooperation, gender equality and the role of women in promoting public policy. The speakers acquainted the participants with the indicators of women's participation in politics, with the national experience of strengthening the women's role in the sociopolitical life of their countries.

Turkmenistan, in 2001, had at least 30 women's organisations and initiative groups that were somewhat active in the donor community, including the Counterpart Consortium (Women's organisations and their use of information and communication technologies in the Caucasus and Central Asia region n. d.). However, these organisations were not registered, in part because the Ministry of Justice believed that the existing quasi-NGOs, the Women's Union, which had more than 700,000 members in its ranks, was enough to solve all the women's problems in the country. Today, the "Women's Union" plays an essential role in the formation of women's civic engagement, conducts a multifaceted and versatile work aimed to increase their political, legal, economic, and medical literacy. The 
Women's Union actively supports contact with the Government.

New women's organisations are recommended to become affiliated members of the Union for obtaining an official status. The Women's Union was registered in 1994. This NGO established a network of related organisations throughout the country, hosting local, city, regional and provincial authorities. The organisation is closely connected with the government. Its offices are mainly located in the offices of the city administration. Regional leaders of the organisation often hold the post of deputy mayor for education, culture and public organisations at the same time. For these reasons, it is sometimes difficult to determine where the government's role ends and the NGO' role begins.

The Women's Union and other women's organisations and initiative groups work in different areas, such as legal advice, legal and civic education, retraining and employment, reproductive health and gender aspects. Partnerships between NGOs, including women's organisations, include the exchange of skills and information. The most developed NGO provide other groups with access computers, office equipment and e-mail. However, the technical and financial resources of these NGO are limited, and their services cannot be provided to a large audience.

Today, Turkmenistan has managed to achieve serious success in gender equality, which was an important factor in the election of Turkmenistan in April 2017 to the Commission on the Status of Women for 2018-2022, which is the structure of the United Nations Organisation. It is also remarkable that two years earlier Turkmenistan was elected to the Executive Council of the UN structure on gender equality and women's empowerment for 2016-2018 (Gender equality n. d.). However, to realise women's potential, there should be more opportunities for women to be actively involved in decision-making processes - both at the state and local levelsas representatives of local administration and executive authorities, representatives of public organisations and local communities.

\section{Conclusion}

Summarising the above, we would like to note that, whatever the relationship of women's organisations to the official authorities in the region is, it is obvious that the future of the women's movement will largely depend on how Central Asian states revise their social policy bases. Obviously, there are several reasons for the current situation. Firstly, the underdevelopment of civil relations in society determines the low activity of women themselves and their lack of faith in the government's decisions. Secondly, the very problem of equality between men and women, the attempt of the women's movement's leaders to separate women's issues as an independent category, do not find proper reflection in public opinion and at the level of state structures. Finally, the mechanisms of interaction between NGOs and state institutions have not been properly developed. The leaders of independent organisations also do not yet fully understand the relevance of social partnership with representatives of state institutions in terms of making decisions in the regional, social and economic transformations.

However, we cannot ignore the fact that instead of defining women's rights as human rights, many countries share the stereotypes resulting in the fact that formal equality rarely goes beyond the official narratives. Practical and real protection of human rights through domestic legislation in the countries of the region is necessary. The union of public organisations and the state is to a certain extent the starting point for the correct and persistent lobbying of women's interests.

At the same time, the bare existence of laws is not enough to change and improve the existing stereotypes. An unwillingness and sometimes even a direct refusal by lawful bodies to apply the legal language, to protect a woman is an obvious sign of the low level of social and cultural environment's development. The law is just a mechanism for women in the struggle for balanced gender equality. 


\section{Endnotes}

${ }^{1} \mathrm{An}$ oblast is a type of administrative division of Russia.

\section{References}

Akhmetova, Ya.S. (2003). Introduction:

Continuation of the excursion into history, or the Golden Period of NGO. In State and NGO in Kazakhstan: interaction experience and forms. Astana: Saryarka.

Alimdjanova, D. (2002). Women's Status in Uzbekistan (draft): Country Briefing Paper. Retrieved January 17, 2018 from http://www.undg.org/archive_docs/5479Uzbekistan_CCA.pdf.

Asian Development Bank. (2014). Gender assessment in Uzbekistan. Retrieved January 17, 2018 from

https://www.adb.org/sites/default/files/institut ional-document/42878/files/uzbekistancountry-gender-assessment-ru.pdf.

Association of Kyrgyzstan Crisis Centers. (n. d.). Retrieved January 17, 2018 from http://neomak7.wixsite.com/accwebkg.

Beasley, C. (1999). What is Feminism?: An Introduction to Feminist Theory, London: Sage

Publications

Bekturganova, K.A. (2009). The historical role of women in the socio-economic and cultural life of Kyrgyzstan (XX century): Thesis by Candidate of Science. Bishkek: Kyrgyz-Russian Slavonic University.

Bhattacharyya, R. (2009). Examining the changing status and role of middle class Assamese women: Lessons from the Lives of University Students. PhD thesis, UK: Newcastle University

Bhattacharyya, R. (2013). Are We Empowered? Stories of young Indian working women, Saarbrücken, Germany: Lap Lambert Academic Publishing, (ISBN: 978-3-659-20580-4)

Bhattacharyya, R. (2017). Sociologies of India's Missing Children, Asian Social Work and Policy Review, 11(1), 90-101, DOI:10.1111/aswp.12116
Bhattacharyya, R. (2018). \# MeToo Movement:

An Awareness Campaign. International Journal of Innovation, Creativity and Change 3(4): 1-12. Retrieved October 302018 from http://www.ijicc.net/images/Mrach18_spec_ed ition/battacharyarra_March18.pdf

Bhattacharyya, R. (2019). Child Sponsorship: Exploring Pathways to a Brighter Future. Progress in Development Studies, 19(1), 83-84, https://doi.org/10.1177/1464993418799895

Bhattacharyya, R. (2015). Understanding the spatialities of sexual assault against Indian women in India, Gender, Place and Culture, 22 (9), 1340-1356, http://dx.doi.org/10.1080/0966369X.2014.9696 84

Bhattacharyya, R., Das, T., Alam, F and Parvin Amina (2018). Researching Domestic Violence in Bangladesh: Critical Reflections, Journal Ethics and Social Welfare, https://doi.org/10.1080/17496535.2018.14588 89, 1-16

Calman, L. (1992). Toward Empowerment: Women and Movement Politics in India, Colorado: Westview

Convention on the Elimination of All Forms of Discrimination against Women. (1994). In Collection of international treaties of the United Nations (Vol. 1). New York, Geneva.

Dahlerup, D. (1986). (ed). The New Women's Movement-Feminism and Political Power in Europe and the USA, London: Sage

Das, T., Alam, F., Bhattacharyya, R. and Parvin, A. (2015). Causes and Contexts of Domestic Violence: Tales of the Help Seeking Married Women in Sylhet, Bangladesh, Asian Social Work and Policy Review, 9(2), 163-176, DOI:10.1111/aswp.12055

Das, T., Bhattacharyya, R. Alam, F., and Parvin, A. (2016). Domestic Violence in Sylhet, Bangladesh: Analysing the Experiences of Abused Women, Journal Social Change, 46 (1), 106-123, DOI: 10.1177/0049085715618561

Dhungel, R., Lama, S., Khadka, A.,Sharda K.C., Sherpa,M., Limbu, P., Limbu, G., Rai, M. and Shrestha, S. (2019). Hearing our Voices: 
Pathways from Oppression to Liberation through Community-Based Participatory Research, Journal Space and Culture, India, 6(5),39-55, https://doi.org/10.20896/saci.v6i5.439

Gender equality is the key to sustainable development. (n. d.). Retrieved January 17, 2018 from http://zenan.gov.tm/content/480.

Gender research: How does Kazakhstan implement a policy on women and men. (n. d.). Retrieved January 17, 2018 from https://www.zakon.kz/4872564-gendernoeissledovanie-kak-v-kazahstane.html.

Hegay, M.N. (1999). Gender and Culture. Dushanbe: "Asia-plus"

Kamp, M. (2007). The New Woman in Uzbekistan: Islam, Modernity, and Unveiling under Communism. États indépendants, 48(4), 798-801.

Karimov, Sh.T. (2015). Role of non-governmental organisations in the formation of civil society in Tajikistan: political analysis. Dushanbe.

Kazakhstan: Domestic sex trafficking is greater than in the UAE, Turkey and Russia. (2015). Retrieved January 17, 2018 from https://www.caravan.kz/gazeta/kazakhstanvnutrennijj-sekstrafik-bolshe-chem-v-oaehturciyu-i-rossiyu-86631/.

Kazakh Women's Movement in the Context of Democratic Transformations in the Republic" (2001). Manual. Astana, 57 pp.

Korostyleva, N.N. (2005). The role of civil society in the development of independent Kyrgyzstan. Bishkek: Russian-Tajik (Slavonic) University (RTSU).

Kumar, R. (1993). The History of Doing-An Illustrated Account of Movements for Women's Rights

and Feminism in India, 1800-1900, New Delhi: Kali for Women

Kurbanova, M.R. (2010). Times of Courage: Women's NGO Movement in Uzbekistan. Retrieved January 17, 2018 from https://etd.ohiolink.edu/!etd.send_file?accessi on=ohiou1273606596\&disposition=inline.
Kuvatova, A. (1997). Public opinion and changes in the Tajik social structure. Dushanbe: RussianTajik (Slavonic) University (RTSU).

Mersiyanova, I.V. (2012). The third sector: definition, terminology, boundaries, research data and development trends. Retrieved January 17, 2018 from http://nko29.ru/files/library/tretii_sektor_opre delenie_terminologiya_granici_dannie_issledov aniya_i_tendencii_razvitiya.pdf.

Mirzoyeva, V.M. (2004). History of the development of the women's movement in Tajikistan for the years of independence: Thesis by Candidate of Science. Dushanbe.

National Plan for the Enhancement of the Women's Status and Role for 1998-2005. (n. d.). Retrieved January 17, 2018 from https://kumitaizanon.tj/index.php/ru/.../91prezidentskaya-kvota-plod-nezavisimosti.

Nurulla-Khodzhaeva, N.T. (2004). Women in a transforming society (by the example of the research on Central Asian states): Thesis by Candidate of Philosophy. Dushanbe.

On the approval of the Concept of Family and Gender Policy in the Republic of Kazakhstan until 2030. Retrieved January 17, 2018 from http://egov.kz/cms/ru/law/list/U1600000384.

On the implementation of the decisions of the Beijing Platform for Action on the Status of Women in respect of women's rights. (2001). Moscow: Women's Association "Femina", pp. 21-56.

"On the National Strategy of the Kyrgyz Republic for Gender Equality until 2020 and the National Action Plan for the Gender Equality in the Kyrgyz Republic for 2012-2014" of June 27, 2012. (n. d.). Retrieved from http://www.gender.cawaterinfo.net/publications/pdf/kg_nat_strat_project. pdf.

Order of the Ministry of Internal Affairs dated 26.10.1999 N 535 "On issuing instructions on the organisation of the work of units of the internal affairs bodies of the Republic of Kazakhstan to combat violence against women". (1999). Retrieved January 17, 2018 
from http://kazakhstan.news-

city.info/docs/sistemsh/dok_oeyvdo.htm.

Ponomaryov, V. (1991). Public organisations in Kazakhstan and Kyrgyzstan in 1987-1991 (experience of the directory). Alma-Ata: MP "Glagol".

Public Association "Gender and Development" and EU, (2004). State Program Main Directions of State Policy on Ensuring Equal Rights and Opportunities for Men and Women in the Republic of Tajikistan for 2001-2010. Retrieved January 17, 2018 from http://www.cawaterinfo.net/library/rus/gender/law_rt_3_ru.pdf

Responses to the list of issues and questions for consideration of the Combined second and third periodic report of Uzbekistan. (2006). Retrieved January 17, 2018, from

http://www.un.org/womenwatch/daw/cedaw/ cedaw36/uzb.pdf.

Review of trends in achieving gender equality in the Kyrgyz Republic. (n. d.). Retrieved January 17, 2018, from

http://www.un.org/womenwatch/daw/Review/ responses/KYRGYZSTAN-Russian.pdf.

Ryan, B. (1992). Feminism and the Women's Movement: Dynamics of Change in Social Movement, Ideology and Activism, New York: Routledge

Sharipova, M. (2002). Violence against women in Tajikistan: the context of the phenomenon being studied. Dushanbe.Shishkarayeva, E.T. (2006). Review of the history of the NGO sector formation and development in Kyrgyzstan. Bishkek.

State and NGO: constructive dialogue. (2004). In Materials of the Civil Forum, Astana, October 14-15, 2003. Astana: MI RK, UNDP.

Statistical Yearbook: Regions of Kazakhstan in 2016. (n. d.). Retrieved January 17, 2018, from stat.gov.kz/faces/wcnav_externalld/publication sCompilations?lang=ru.

Syrtykbayeva, D. (1999). Woman's Image in the Kyrgyzstan Media. In Sotsiologiya i pravo. Bishkek, pp. 57-148.
National strategy of activating the women's role in the Republic of Tajikistan for 2011-2020. (n.

d.). Retrieved January 17, 2018 from http://www.gender.cawaterinfo.net/publications/pdf/tj-269-2010.pdf.

The National Action Plan on Gender Equality presente. (n. d.). Retrieved January 17, 2018 from

http://turkmenistan.unfpa.org/news/nationalaction-plan-gender-equality-presented.

The State Program "Main Directions of the State Policy on Ensuring Equal Rights and Opportunities for Men and Women in the Republic of Tajikistan for 2001-2010" (as amended by Decree of the Government of the Republic of Tajikistan of April 30, 2004 No. 196). (n. d.). Retrieved January 17, 2018 from http://www.adlia.tj/show_doc.fwx?Rgn=12883.

The UN Convention on the Child's Rights. (2002). Moscow: INFRA.

Union of Economists of Turkmenistan and United Nations Development Program of Turkmenistan, (2008). Gender and Business in Turkmenistan. Ashgabat.

Vauquline, P. (2015). Socialisation Process, Power Relations and Domestic Violence: Marginal Voices of Assamese Women. Space and Culture, India, 3(2), 54-71. https://doi.org/10.20896/saci.v3i2.155

Watson, B. and Clarke, M. (2014). Child Sponsorship: Exploring Pathways to a Better Future, London: Palgrave Macmillan

Women's movement in Kazakhstan: Ten years of history. (n. d.). Retrieved January 17, 2018 from https://www.caravan.kz/articles/zhenskoedvizhenie-kazakhstana-desyat-let-istorii376298/.

Women's NGO are united in a coalition. (2001). The Panorama, 42. Retrieved January 17, 2018 from http://panoramakz.com/archiv/2001/42.htm.

Women's organisations and their use of information and communication technologies in the Caucasus and Central Asia region: an exploratory assessment. Retrieved January 17 , 2018 from 
http://un.an1.un.org/intradoc/groups/public/d Women's Aid Center [Tsentr pomoschi ocuments/un-dpadm/unpan044822.pdf.

Women's Committee of Uzbekistan, Gender and Development Bureau and UNDP, (1999).

National Platform for Action on the zhenschinam] (n.d.) Retrieved January 17, 2018 from http://wsc.host.net.kg

Yailymova, A. (2017). One step forward, two steps back: 25 years of women's rights of Improvement of Women's Status in Uzbekistan and on Advancement of Women in the Society. Tashkent, September 1999. Turkmenistan. In Central Asia - 25: thoughts about the past, projection of the future. Collection of essays from Central Asia. Washington. 